\title{
Through the Looking Glass: Creeping Vulnerabilities and the Reordering of Security
}

\author{
P. H. LIOTTA* \\ Pell Center for International Relations and Public Policy, \\ Newport, RI, USA
}

\begin{abstract}
Although security - as a basic concept - is frequently considered in the study and analysis of policy decisions, its essential meaning ought to be more widely disagreed than agreed upon. Commonly considered a basic concept in policy and academic debates, security is in reality a quantity that is not basic at any register. The couching of emerging 'non-traditional' concepts such as environmental security and human security solely on their relationship to potential or real threats, most often within a topology of power, and the use of language that is inadequate to the often nuanced and almost always complex dynamics of such emerging identities imprisons such concepts within 'traditional' state-centered, national security paradigms. Moreover, not all security issues involve 'threats'; rather, the notion of vulnerabilities is as serious to some peoples, and some regions, as the more familiar concept of threat. The issue truly is not one of 'hard' traditional security (often based on state-to-state power relationships) or 'soft' non-traditional security (which can involve multiple transnational aspects), but rather the need for a focus on both. Too exclusive a focus on one form of security may cause a boomerang effect', resulting from failure to recognize, or deal with, other contending forms of security. Recognizing and acting on the best approaches to issues of security will prove the greatest challenge.
\end{abstract}

Keywords security as concept $\cdot$ threats $\cdot$ vulnerabilities $\cdot$ policy implications

\footnotetext{
A LTHOUGH SECURITY - as a basic concept - is frequently considered in the study and analysis of policy decisions, its essential meaning ought to be more widely disagreed than agreed upon. ${ }^{1}$

${ }^{1}$ In recent debates, including those in Security Dialogue, there has been a proliferation of descriptors added to the basic term 'security'. Each of these descriptors lends a perhaps slightly different connotation. To
} 
Commonly considered a basic concept in policy and academic debates, security is in stark reality a quantity that is not basic at any register. Moreover, as one of the reviewers of an earlier version of this article noted, oftentimes in debates an issue is framed as a security 'referent' almost exclusively in terms of 'threat' and causal, seemingly inevitable, linkages to violence.

However, allowing such intellectual carelessness leads all who study and practice security into dangerous territory. The couching of emerging 'nontraditional' concepts such as environmental security and human security solely on their relationship to potential or real threats, most often within a topology of power, and the use of language that is inadequate to the often nuanced and almost always complex dynamics of such emerging identities imprisons such concepts within 'traditional' state-centered, national security paradigms.

To be blunt, those intending to affect the debate have specific reasons for using such (perhaps unintentional) strategies: doing so both makes the topic accessible for decisionmakers and provides a basis for determining present and future policy. Most often, decisionmakers only conceive of security concepts within a power-dominant, state-centric mindset. There is a risk, nevertheless, in adding the term 'security' to either environmental or human-centered concerns. Furthermore, conflating national security, human security, and environmental security all within a distinct conceptual framework is not just precarious; it also entails potential hypocrisy. While this is admittedly a contentious claim, sure to provoke debate, the time has come to recognize some hard certainties in an increasingly complex, uncertain world.

Not all security issues involve 'threats'; rather, the notion of vulnerabilities is as serious to some peoples - and some regions - as the familiar 'threat' metaphor of armies massing at the borders or barbarians at the gates. Equally, not all security issues need be directly linked to violence. One of the most serious future security issues discussed in this article, rapid urbanization in the Lagos-Cairo-Karachi-Jakarta arc, is a clear, emerging example of a 'creeping vulnerability' - yet its inevitable linkage to violent outcomes is not at all clear at present.

Thus, an important acknowledgment should emerge here: those who form policy and make critical decisions on behalf of states and peoples must, ever increasingly, focus both on aspects of traditional 'national security', in which

\footnotetext{
speak of economic security, geographic security, gender security, cultural security, environmental security, ethnic security, military security, physical security, psychological security, political security, societal security, or human security suggests specific (and probably necessary) recognitions, and also unduly privileges such recognitions with discrete identities that depend on, and often cannot exist without, other identities. Admittedly, some of these security distinctions establish important linkages to policy and security decisions. Two recent examples linking security to globalization and gender, respectively, are Kay (2004) and Hoogensen \& Rottem (2004).
} 
military forces will likely continue to play a pre-eminent role, and on human security, in which 'non-traditional' security issues predominate and where other approaches will take center stage. If such a premise proves true, and in a future where both 'hard' and 'soft' security will matter, those involved in policy decisions (and those affected by such decisions) will increasingly need to focus on aspects of both threats and vulnerabilities. There is a crucial need, then, to recognize the difference between these two categories.

A threat is identifiable, often immediate, and requires an understandable response. Military force, for example, has traditionally been sized against threats: to defend a state against external aggression, to protect vital national interests, and to enhance state security. (The size of the nuclear arsenals of the USA and the USSR during the Cold War made perhaps more sense then than now, because the perceived threat of global holocaust in the context of a bipolar, ideological struggle was far greater then.) A threat, in short, is either clearly visible or commonly acknowledged.

A vulnerability is often only an indicator, often not clearly identifiable, often linked to a complex interdependence among related issues, and does not always suggest a correct or even adequate response. While disease, hunger, unemployment, crime, social conflict, criminality, narco-trafficking, political repression, and environmental hazards are at least somewhat related issues and do affect the security of states and individuals, the best response to these related issues, in terms of security, is not at all clear. While Canada, for example, has emphasized the relevance of human and environmental security to 'high politics', and has attempted to restructure its armed forces to meet such challenges, the relevance of military state-centered forces in addressing or 'solving' non-state-centered issues is questionable.

Moreover, a vulnerability (unlike a threat) is not clearly perceived, often not well understood, and almost always a source of contention among conflicting views. Compounding the problem, the time element in the perception of vulnerability must be recognized. Some suggest that the core identity in a security response to issues involving human or environmental security is that of recognizing a condition of extreme vulnerability. Extreme vulnerability can arise from living under conditions of severe economic deprivation, or among victims of natural disasters and people caught in the midst of war and internal conflicts. Long-term human development attempts thus make little to no sense and offer no direct help. To be blunt, the situation here is not one of sustainability, but of rescue.

R. H. Tawney, describing rural China in 1931, described the extreme vulnerability among peasants through a powerful image: 'There are districts in which the position of the rural population is that of a man standing permanently up to the neck in the water, so that even a ripple is sufficient to drown him' (Scott, 1997: 1). In such instances, the need for intervention is immediate. 
But there are also cases of long-term vulnerability, in which the best response is uncertain. I have termed these problematic conditionalities which are most difficult for policy analysts and decisionmakers, who are often driven by crisis response rather than the needs of long-term strategic planning - creeping vulnerabilities. Given the uncertainty, the complexity, and the sheer non-linear unpredictability of creeping vulnerabilities, the frequent - and classic - mistake of the decisionmaker is to respond with the 'gut reaction': the intuitive response to situations of clear ambiguity is, classically, to do nothing at all. The more appropriate response is to take an adaptive posture: to resist the urge to act purely on gut instinct and to recognize what variables, indicators, and analogies from past examples might best inform the basis of action (Courtney, Kirkland \& Viguerie, 1997).

To be clear: avoiding the disastrous long-term impacts of creeping vulnerabilities (which can evolve over decades) requires strategic planning, strategic investment, and strategic attention. To date, states and international institutions seem woefully unprepared for such strategic necessities. Moreover, environmental and human security, since they are contentious issues, often fall victim to the do nothing response because of their vulnerability-based conditions, in which clearly identifiable causes and effects that decisionmakers desire to prevent are often ambiguous.

In essence, we have moved from the dynamic of the traditional security dilemma to encompass issues in the 21st century that will include a new human dilemma in specific geographic locations, requiring sustainable development and long-term investment strategies. Plausible 'creeping vulnerability' scenarios thus might reasonably include:

- different levels of population growth in various regions, particularly between the 'developed' and the 'emerging' world, including disproportionate population growth (youth bulges) and historically unprecedented levels of urbanization;

- the outbreak and rapid spread of disease among specific 'target' populations (such as HIV / AIDS), as well as the spread of new strains of emerging contagion (such as SARS);

- significant climate change due to increased temperatures, declines in precipitation, and rising sea levels;

- scarcity of water (in specific regions for drinking and irrigation, and the compounding growth among populations dependent on trans-boundary water resources) and other natural resources;

- declines in food production and increasing needs for imported goods;

- progressing soil erosion and desertification;

- increased urbanization and pollution in 'megacities' (with populations of ten million or more) around the globe. (In particular, in the Lagos-CairoKarachi-Jakarta arc, most people will migrate over the next two decades 
to urban environments that lack the necessary infrastructure to support rapid, concentrated population growth);

- the need to develop warning systems for natural disasters and environmental impact - from earthquakes to land erosion. ${ }^{2}$

These emerging vulnerabilities will not mitigate or replace more traditional hard security dilemmas. Rather, we will see the continued reality of threatbased conditions contend with the rise of various vulnerability-based urgencies. Paradoxically, creeping vulnerabilities will likely receive the least attention, even as their interdependent complexities grow increasingly difficult to address over time. ${ }^{3}$

A powerful illustration of urbanization shifts as creeping vulnerability is relevant here. Truly cataclysmic demographic changes will occur in the Lagos-Cairo-Karachi-Jakarta arc, where there will be astounding shifts in the global landscape that hinge on the 'flocking' of populations to urban centers. According to the National Intelligence Council's (2001) Global Trends 2015: A Dialogue About the Future with Non-Governmental Experts, as well as data compiled for the November 2003 issue of National Geographic magazine, world population is expected to rise to 7.2 billion in 2015, and most will tend to live longer than they do today. Some $95 \%$ of the increase will take place in 'emerging' countries, and nearly all of this population growth will happen in rapidly expanding urban areas (National Intelligence Council, 2001).

Consider, for example, the difference between growth in the emerging world versus growth in the so-called developed world, looking at figures from 1950 to projected figures for 2015: New York City will go from 12 million inhabitants in 1950 to 17 million in 2015, while Lagos will grow from 1 million to 24.4 million in the same period; Los Angeles will shift from 4 million to 14.2 million, while Karachi will explode from 1.1 million to 20.6 million. Yet, while Tokyo will admittedly mushroom from 6.2 million to 28.7 , it will likely be far better equipped and able to handle the infrastructure requirements of the future 'megacity' - unlike many cities in the emerging world.

Urbanization of itself, however, is value-neutral - neither a good nor a bad thing. Urbanization, therefore, does not have to suddenly become a security issue or a threat. While Tokyo, for example, will remain the world's largest populated city, in many ways Japan has already accommodated for its urbanized existence (72\% of Japanese today live in cities). It is unclear,

2 These points are partially influenced by Brauch (2000: 283-286, 304-306).

${ }^{3}$ Admittedly, suppositions here that insist on a distinction between threat and vulnerability become somewhat suspect in the so-called Age of Terror. While no one doubts that certain states and actors are under 'threat' from al-Qaeda and Jemaah Islamiyah, the shadowy nature of such loosely grouped networks defies the traditional sense of threat. Loose terrorist 'networks' often display the following characteristics: the ability to operate effectively as a lateral (and non-centralized) network, the ability to learn, the capacity to anticipate, and the capability to 'self-organize' or reconstitute after they have been struck (Liotta, 2002b). As a result, such networks operate on the faultline between threat and vulnerability, and too narrow a focus on either 'threat' or 'vulnerability' will only lead to frustration, and ultimately failure. 
however, whether Lagos, Dhaka, or Tehran can sustain growth rates such as those projected above. Indeed, it is not even clear whether many cities in developed states could sustain such rates. If New York City were to grow at the same rate as that projected for Dhaka between 1950 and 2015, the Big Apple (that is, the really Big Apple) would in 2015 have a population just shy of 600 million - roughly twice the current population of the United States. As it seems unlikely that advanced polities such as New York city and state would be able to sustain such rapid growth levels, how can we assume that Bangladesh - already one of the most impoverished states on the face of the earth - could possibly accommodate a dramatic surge in the population of its capital city?

The real effect of urbanization, and where it will most rapidly take place, reveals itself in the projection for the year 2015, where the number of cities with a population of over five million will skyrocket from 8 (in 1950) to 58. Additionally, various population studies suggest that it could be possible to see more than 600 cities worldwide with populations in excess of one million inhabitants by 2015. In 1950, by contrast, there were only 86 such cities on the planet.

Given the extended example of urbanization as a creeping vulnerability, it should not be difficult to grasp why the other vulnerabilities listed above youth bulges, disease outbreaks, climate change and human impact, resource scarcity, soil erosion and desertification - are interconnected. As one factor tends to distort beyond control, other factors tend to follow.

Moreover, all of these factors lead to what Richard Norton (2003) of the US Naval War College has described as the 'Feral City' syndrome: cities that have grown beyond the 'natural' carrying capacity of their respective national and civic governments to provide sufficient security within 'pockets of darkness' in their municipal boundaries. Feral cities will exist within states, nonetheless, clearly linked to the globalization process - with commercial, communications, and transportation links to the rest of the world. Examples include the favelas in Rio de Janeiro or ungovernable areas in Johannesburg and Gauteng Province in South Africa.

Violent crime and sexual offenses, furthermore, now account for almost one-third of reported offenses in many urban environments in the emerging world. In Rio de Janeiro, murder rates reach 60 per 100,000 residents; in Calcutta, 91 per 100,000; and in Johannesburg, 115 per 100,000 (United States Government Interagency Working Group, 2000; Buvinić \& Morrison, 2000; Zvekić \& del Frate, 1995: 24; United Nations Centre for Human Settlements, 1996: 23). In Rio, where the infamous Brazilian favelas have long been under criminal control and where policing actions are unable to cope or to control activity within these feral zones, many favelados feel marginalized and live in a pervasive atmosphere of fear - as much afraid of the police as of drug lords (Perlman, 2002). 
In Karachi, the most violent and lawless city in Asia, $40 \%$ of the population inhabit katchi abadis (slums), a fertile base for radical Islamism. The city itself (Pakistan's largest, and its biggest seaport) is a conduit for arms smuggling to the outside world. In Lagos, Nigeria, the city's population is also expected to mushroom. Lagos suffers from high unemployment and massive youth bulges, and it is the nucleus of constant turmoil. Indeed, fighting in Lagos between the Yoruba and ethnic Hausa is thought to have far more to do with poverty and lack of opportunity than ethnic hatred. Lagos is also the center of Africa's international criminal network, and pervasive crime and corruption have crippled the economy, contributed to social and political tensions, and undermined relations with major potential trading partners in North America and Europe.

A second example of creeping vulnerability, one in which outcomes do not necessarily lead to violence, can be seen in the complex interrelationship between water use, agriculture, and the emerging societies and lifestyles of the future that will consume even greater amounts of resources. To briefly offer an example of this complex, yet potentially serious, creeping vulnerability, consider that in 1900, 1.6 billion people populated the earth; in 2000, that number reached 6 billion. In 1900, a US male had a life expectancy of 47 years; in 2000, that life expectancy reached 77 years. Notably, an explosive increase in annual levels of water consumption from 1900 to 2000 - from roughly 500 cubic kilometers to 5,000 cubic kilometers - was not directly linked to increased population growth. Rather, the real 'explosion' in water usage (where over the past three centuries water consumption has grown by a factor of 45) has been in agriculture, which accounts for around $70 \%$ of all water use (Montaigne, 2002: 16). Yet, the problem becomes even more complicated.

By around 1960, all available arable land had been taken into use, and it was thus impossible to increase agricultural production simply through geographic expansion. Since then, the world's population has doubled, and grain yields - wheat, rice, corn - have tripled through more intensive forms of agricultural production. As an example of how a 'developed' state abuses water resources to maintain a developed lifestyle, consider the following: $82 \%$ of US cropland - corn, unprocessed wheat, hay, soybeans - is not grown for direct consumption. Rather, it is grown for other food sources, such as refined and processed foods, and feed for livestock. Around $80 \%$ of the grain produced in the USA - wheat, rice, corn - goes to livestock. Much of the emerging world is following the USA's example. In 1960, Mexico fed 5\% of its grain to livestock; today, it does the same with $45 \%$ of its grain. Egypt went from $3 \%$ to $31 \%$ over the same time period. China, with one-sixth of the world's population, has gone from 8\% to 26\% (Manning, 2004: 43-45).

This second example, in particular, reveals how 'creeping' vulnerabilities unlike threats - cannot be couched exclusively in terms of negative outcomes. On the contrary, these vulnerabilities present opportunities, cha- 
llenges, and risks, and there is a serious need to recognize and adapt to their increasing influences. Moreover, failing to recognize the resident strengths or weaknesses in how states will continue to act in the future to new and old security challenges may well lead to what I have previously termed a 'boomerang effect' (Liotta, 2002a,c).

Perhaps the best way to illustrate this is through a personal anecdote. I grew up in Australia. I recall one weekend in Queensland when, after exploring several opal mines, my father decided to 'try out' a new killer boomerang. The weapon was heavy enough to be lethal, yet apparently light enough to return when thrown. And sure enough, with the family gathered in an open field, my father heaved a mighty toss and the weapon worked as advertised. To our amazement, the boomerang arced several hundred meters into the air; to our horror, the boomerang then started to return. My father, my two brothers, and I fled to all four quadrants of the compass. My mother, frozen in place, caught the full impact of the massive boomerang. She has never truly forgiven any of us.

So it may be for states in the international system of the future. The issue truly is not one of 'hard' traditional security (often based on state-to-state power relationships) or 'soft' non-traditional security (that can involve multiple transnational aspects) - but rather the need for a focus on both. Too exclusive a focus on one form of security may cause a boomerang effect, through failure to recognize, or deal with, another contending form of security. Recognizing and acting on the correct approaches to such security issues will prove the greatest challenge.

\section{New and Old Security}

In the classical sense, security - from the Latin securitas - refers to tranquility and freedom from care, or what Cicero termed the absence of anxiety upon which the fulfilled life depends. Notably, numerous governmental and international reports that focus on the terms 'freedom from fear' and 'freedom from want' emphasize a pluralist notion that security is a basic, and elemental, need.

Yet, in the once widely accepted realist understanding, the state was the sole guarantor of this absence of anxiety: security extended downwards from nations to individuals; conversely, the stable state extended upwards in its relations to influence the security of the international system. Individual security, stemming from the liberal thought of the Enlightenment, was also considered both a unique and a collective good. ${ }^{4}$ Moreover, despite the

\footnotetext{
${ }^{4}$ Adam Smith, for example, in The Theory of Moral Sentiments, mentions only the security of the sovereign, who possesses a standing army to protect him against popular discontent and is thus 'secure' and able to
} 
abundance of theoretical and conceptual approaches in recent history, the right of states to protect themselves under the rubric of 'national security' and through traditional instruments of power (political, economic, and especially military) has never been directly, or sufficiently, challenged. The responsibility, however, for the guarantee of the individual good - under any security rubric - has never been obvious.

It does seem significant that aspects of 'non-traditional' security issues that have long plagued the so-called developing world - issues that include environmental degradation, resource scarcity, epidemiology, and transnational issues of criminality and terrorism - can also increasingly affect the policy decisions and future choices of powerful states and world leaders. As disparate as these 'non-traditional' issues may be, the 'developed' world is now confronted with similar, human-centered vulnerabilities that had often been present previously only for developing regions. The implications of this changing security environment for the analyst and policymaker are therefore potentially profound.

The future may well require decisionmakers to focus on a broad - and broadening - understanding of the meaning of security. The 1994 UNDP Human Development Report, for example, attempted to highlight a conceptual shift that needed to take place:

The concept of security has for too long been interpreted narrowly: as security of territory from external aggression, or as protection of national interests in foreign policy or as global security from the threat of nuclear holocaust. It has been related to nation-states more than people. ... Forgotten were the legitimate concerns of ordinary people who sought security in their daily lives. For many of them, security symbolized protection from the threat of disease, hunger, unemployment, crime [or terrorism], social conflict, political repression and environmental hazards. With the dark shadows of the Cold War receding, one can see that many conflicts are within nations rather than between nations. (UNDP, 1994: 3, 22-23)

In 2003, the UN Commission on Human Security expanded such a concept of security to include protection for peoples suffering through violent conflict, for people on the move (whether migrants or refugees), and for people in post-conflict situations, as well as the responsibility to improve conditions of poverty, health, and knowledge.

Essentially, states and regions, in a globalized context, can no longer afford to solely emphasize national security issues without recognizing that abstract concepts such as values, norms, and expectations also influence both choices and outcomes. Societies, whether in the emerging or in the 'developed' world (admittedly, a rather arrogant term), are increasingly

allow his subjects the liberty of political 'remonstrance'. In contrast, M. J. de Condorcet's argument, in the late 18th century, suggested that the economic security of individuals was an essential condition for political society; fear - and the fear of fear - were for Condorcet the enemies of liberal politics These distinctions are ably considered in Rothschild (1995). 
Table 1. Alternative 'Security' Concepts

\begin{tabular}{|c|c|c|c|c|}
\hline $\begin{array}{l}\text { Traditions and } \\
\text { analytic bases }\end{array}$ & Security type & $\begin{array}{l}\text { Specific security } \\
\text { focus }\end{array}$ & $\begin{array}{l}\text { Specific security } \\
\text { concerns }\end{array}$ & $\begin{array}{l}\text { Specific security hazards } \\
\text { (threats/vulnerabilities) }\end{array}$ \\
\hline Non-traditional & Environmental security & The ecosystem & Global sustainability & $\begin{array}{l}\text { Mankind: through resource } \\
\text { depletion, scarcity, war, and } \\
\text { ecological destruction }\end{array}$ \\
\hline Traditional, realist-based & National security & The state & $\begin{array}{l}\text { - Sovereignty } \\
\text { - Territorial integrity }\end{array}$ & $\begin{array}{l}\text { Challenges from other states } \\
\text { (and 'stateless' actors) }\end{array}$ \\
\hline $\begin{array}{l}\text { Traditional and } \\
\text { non-traditional, realist- } \\
\text { and liberal-based }\end{array}$ & 'Embedded' security & $\begin{array}{l}\text { - Nations } \\
\text { - Societal groups } \\
\text { - Class/economic } \\
\text { - Political action } \\
\text { committees/interest groups }\end{array}$ & $\begin{array}{l}\text { - Identity/inclusion } \\
\text { - Morality/values/ conduct } \\
\text { - Quality of life } \\
\text { - Wealth distribution } \\
\text { - Political cohesion }\end{array}$ & $\begin{array}{l}\text { - States } \\
\text { - Nations } \\
\text { - Migrants } \\
\text { - Alien culture }\end{array}$ \\
\hline $\begin{array}{l}\text { Non-traditional, } \\
\text { liberal/Marxist-based }\end{array}$ & Human security & $\begin{array}{l}\text { - Individuals } \\
\text { - Mankind } \\
\text { - Human rights } \\
\text { - Rule of law } \\
\text { - Development }\end{array}$ & $\begin{array}{l}\text { - Survival } \\
\text { - Human progress } \\
\text { - Identity and governance }\end{array}$ & $\begin{array}{l}\text { - The state itself } \\
\text { - Globalization } \\
\text { - Natural catastrophe and change }\end{array}$ \\
\hline
\end{tabular}


witnessing an unfolding tension: While states have expectations to protect citizens, citizens increasingly have expectations as well and will hold states accountable.

Within the debate on human security, there has emerged an increased focus on the rights of the individual. This debate has led to intriguing possibilities and, most definitely, uncertain outcomes. It thus remains unclear whether an ethical and collective policy to support human security will be the focus of most states in the future, or whether any such policy could logically be de-linked from a systematic association with power and powerful states.

In such an environment, to avoid the 'boomerang effect', decisionmakers and policy analysts will need to focus on multiple aspects of security. Despite the 'clean' distinctions made in Table 1, there are dangers in too closely following the precepts of one security concept at the expense of another. ${ }^{5}$

Some brief explanation of the concepts used in the table might prove useful. In essence, the distinctions move from a 'top down' global emphasis to a 'bottom up' individual focus.

Environmental security emphasizes the sustained viability of the ecosystem, while recognizing that the ecosystem itself is perhaps the ultimate weapon of mass destruction. In 1666 in Shensi province, for example, tectonic plates shifted; by the time they had settled back into place, 800,000 Chinese were dead. Roughly 73,500 years ago, a volcanic eruption in what is today Sumatra was so violent that ash circled the earth for several years, photosynthesis essentially stopped, and DNA samples suggest that the precursors to what is the human race amounted to only several thousand survivors worldwide. Yet, from an alternative point of view, mankind itself is the ultimate threat to the ecosystem. Thus, from a radically extreme perspective, elimination of humanity proves the ultimate guarantee of the ecosystem's survival.

National security represents the traditional understanding of security, to include the protection of territory and citizens from external threats - from other states and, more recently, 'stateless' actors (which range from NGOs to terrorist networks). Hyper-emphasis on state security, especially in the emergence of 'homeland security', affects the two following concepts of

${ }^{5}$ Earlier versions of this still-evolving table were partially inspired by Møller (2003) and Møller's earlier presentation of his work at the 4th Pan-European International Relations Conference, Canterbury, UK, 5-10 December 2001, as well as work presented to the Faculty of Civil Defence in Belgrade, Serbia, and published in Ljudska Bezbednost 1(1) under the title 'National, Societal and Human Security'. Notably, the above table is markedly different in several critical areas. The present author fundamentally argues, through the use of the 'boomerang effect' example, that those in the so-called Copenhagen School notably Wæver, Buzan and de Wilde (Wæver, 1995; Buzan, Wæver \& de Wilde, 1998; Buzan \& Wæver, 2003; Buzan, 2004) - who have focused on the terms 'referent object', 'societal security', and 'desecuritzation' are inevitably delinking their arguments from effective use in the foreseeable future for the policy decisions of most states. 
security, especially regarding the practice of individual liberties and the freedom to participate openly in civil society.

Embedded security is not synonymous with the more commonly used term 'societal security'. Rather, embedded security is somewhat symbiotically (perhaps parasitically) linked to other security concepts. It often represents the narrow interests of specific communities, nations, or political action groups within a state. In its extreme form, it can lead to social stratification, the fracturing of 'common' interests, and xenophobia. Samuel P. Huntington, all normative judgments aside, focused on such embedded security groups in his 2004 work Who Are We? Challenges to America's National Identity. Moreover, exit-polling data from the US elections in November 2004 indicate that the single most important criterion in the choice of candidate for US president was 'moral values' (22\% of all those polled) - which were thus seen as more important than how a president would deal with economics, foreign policy, terrorism, the war in Iraq, education, or healthcare. Although the term 'moral values' is loaded with ambiguity, it represents a form of parasitic embedded security. In the example of the US election, one specific interest group - Christian evangelicals - associated most with 'moral values' and had the most influence on the election's outcome.

Human security, aside from common agreement on the focus on the individual, is still an emerging concept. ${ }^{6}$ In the September 1999 issue of Security Dialogue, Astri Suhrke (1999) pointed to a fundamental bifurcation that human security as conceptual approach and policy principle continues to suffer from: Is it related more to long-term 'human development', as was suggested in UNDP's 1994 Human Development Report, or (as a security issue) does it constitute a principle of intervention during immediate crisis, as in Rwanda in 1994, Kosovo in 1999, or even Iraq in 2003? The answer to either question is 'nes' - a little bit of 'no', and a little 'yes'.

Thus, while some (including this author in the past) have argued that there may be a growing convergence between what was traditionally called 'national security' and the still developing concept of 'human security', there appears to be an even more powerful counter-argument in which the opposite trend is apparent. ${ }^{7}$ In interventions as disparate as those in Somalia in 1993, in Liberia (at various stages of disintegration), in the Balkans, and in Iraq in 2003, there has emerged an overt increase in US and British hegemonic behavior, accompanied by an uneven commitment to issues involving

${ }^{6}$ A sufficient review of the literature of human security is not possible here. Some of the most stimulating pieces on the subject of environmental and human security are Møller (2003) and Gleditsch (2003). Other work includes Nef (1999), Paris (2001), Stoett (1999), Thomas \& Wilkin (1999), Stiglitz (2002), Tehranian (1999) Matsumae \& Chen (1995) and Khong (2001). In addition, a recent issue of Security Dialogue (2004) revealed the rich diversity and division of perspectives on the topic of what is 'human security'. Here, Taylor Owen's (2004) concluding essay is especially useful.

7 For one perspective that suggested that a convergence between human and national security was occurring in the period following 11 September 2001, see Liotta (2002a), as well as the rejoinder by Smith-Windsor (2002) and a further reply by Liotta (2002c). 
human security. While UK Prime Minister Tony Blair could speak of 'universal values' and US President George W. Bush proclaimed that 'freedom is the non-negotiable demand of human dignity', foreign policy choices regarding intervention were almost exclusively made when such choices satisfied the narrow, selfish, and direct 'national security interests' of more powerful states (Blair, 1999; Bush, 2002). If such choices also satisfied certain aspects of human security, then all the better.

Yet, as the blatant failure of the international community to do anything in 1994 in Rwanda illustrates - other than a collective international decision to do nothing - human security is hardly proving to be the trump card of choice in decisions by states to intervene in the affairs of other states. In other words, taken to extreme forms, both human security and national security can be conceptually approached as antagonistic rather than convergent identities. Each, in its exclusive recognition, remains problematic.

So-called ethical practice in foreign policy that acts on the behalf of individual citizens, for any state - not just the United States - is most accommodated (and accommodating) when such action 'meshes' with achieving the ends of more traditional national interests of the more powerful state. As a basis for international action, we have yet to achieve a consensus on what constitutes 'international interests', who should support them, and who should uphold them.

Human security, both as conceptual approach and as policy principle, thus rests uncomfortably on the horns of a dilemma. While the effort to promote human security in the arena of 'high politics' on the part of the Canadian and Norwegian governments since the 1990s is well known, there is also a tempting sense of proselytizing righteousness. Such so-called middle-power states, after all, can exercise significant moral clout by emphasizing that the rights of the individual are at least as important as protecting the territorial and sovereign integrity of the state. Yet, when larger powers, particularly those with significant militaries (such as the United States or the United Kingdom) advocate similar positions, it is their overwhelming power that is recognized, respected, and resented.

On the one hand, what is perceived as the 'moral clout' of the middle power is sensed as 'hegemony unbridled' when it is emphasized in an attempted similar fashion by major powers. On the other hand, when actions taken in the name, or in the principled pursuit, of human security do occur, they are often inextricably linked to issues that are embedded in the more traditional concepts of 'national security' and protection of the state. Idealism thus becomes enmeshed in realism; actions taken on behalf of the powerless are determined only by the powerful. ${ }^{8}$ As George Packer (2004: 32)

8 Accordingly, we witness 150,000 US forces deployed to Iraq in 2003, but only six communications, command, and control specialists initially put ashore in Liberia to support Nigerian peacekeepers in stability and security operations. Nominally, both scenarios involve regime change and stabilizing regional 
notes, referring to the interventions in both Kosovo and Iraq and the statedeclared reasons for them: 'The [Bush administration] has given idealism a bad name, and it will now take years to rescue Václav Havel from Paul Wolfowitz'.

Undoubtedly, increasing numbers now speak out on behalf of what the International Commission on Intervention and State Sovereignty has termed the 'responsibility to protect': the responsibility of some agency or state (whether it be a superpower such as the United States or an institution such as the United Nations) to enforce the principle of security that sovereign states owe to their citizens. But the dark side to this proposition, of course, is that the 'responsibility to protect' also means the 'right to intervene'. In the topology of power, dominant states will intervene at the time and place of their choosing.

My argument, therefore, in examining the unfolding security realities that have emerged in recent history, is to focus on multi-level, multi-referent, and interdependent aspects of security. If we fail to do this, the boomerang will come arcing back toward us. Indeed, we may well never know what, eventually, will hit us.

\section{An Ethical Framework for Security?}

It would be reasonable at this juncture to consider what role the 'ethics of security' might play in the current and future security environments. According to H. Richard Niebuhr, a responsible ethics (which would encompass an ethics of intervention) embraces the Greek concept of themis, the law of the community that is based on the essential principle of justice; attempts to encompass an 'interaction of response', accountability, and social solidarity; and is driven by a social process that is responsive and accountable to nothing less than an 'international community' (Niebuhr, 1978: 52, 61-65, 88).

Admittedly, a paradigm of responsible security ethics proves difficult, although its governing principles have far-reaching implications. Yet, it does

\footnotetext{
security, as well as intervention for the protection of citizens abused by the state. Yet, the physical and economic geography of Iraq places it at the center of a region declared 'vital' to US interests, awash in petroleum and natural gas resources. National security interests, in the form of geopolitics, again trump the intervention priority list. Moreover, the alleged bellicosity of the former Iraqi regime, particularly regarding potential or actual weapons of mass destruction, clearly supported more traditional national security interests, such as defense of the homeland and protection of one's territory from attack. Liberia, while clearly a regional troublemaker, never posed a 'threat' to the United States or any of its close allies. (Make no mistake, though: this was a brutal, authoritarian regime that threatened its own people as well as the entire security architecture of West Africa, but it remained little more than a perceived peripheral threat for many.)
} 
seem appropriate to ask whether there is a need, or even a possibility, for establishing a framework for ethical security action, including when to intervene. While some have focused on establishing 'capabilities' to determine basic economic, social, and human needs, it might also be appropriate to consider whether or not it is also possible to establish an ethical framework for security. ${ }^{9}$ The driving force of responsible security ethics entails assessment of both the sovereignty of a state and the 'responsibility' of external states to provide support for a state's continued survival. The Iraq intervention in 2003 , in principle at least, was partially based on the belief that 'social justice, participatory freedom, and economic development' would help 'liberate' the Iraqi people, remove Saddam Hussein from power, and mitigate the proliferation of weapons of mass destruction (Barbour, 1993: 26). Even as Grayson $(2003,2004)$ emphatically stresses that treating (specifically human) security policy as an ethos - indeed even a critical transformative ethos - is essential, it remains unclear why an ethos of national security, in principle, should be by any means markedly different than the practice of human security, even one based on reciprocity.

While Reinhold Niebuhr believed that disparities between states were inevitable and that states, like human beings, have an innate desire to dominate others, even Niebuhr, in his work Moral Man and Immoral Society, assented to the idea that 'the goal of modern man must be a society in which there will be enough justice, and in which coercion will be sufficiently non-violent to prevent his common enterprise from issuing into common disaster' (Niebuhr, 1932: 22). John Rawls (1971: 453-454) adequately defined this 'well-ordered society' in the broadest sense as 'one designed to advance the good of its members and effectively regulated by a public conception of justice'. Equally, Rawls emphasized the plurality of support for the common acceptance of the principles of justice and the essential requirement for institutions that satisfy these principles. This ideal, as Timothy Garton Ash (1998: 64-65) notes, is also the essential complex tension that characterized 20thcentury Europe and ought to characterize the future order.

Oftentimes, paradoxically or not, moves toward resolution of human security dilemmas occur only after the application of force, most often national security military force. But this outcome may not prove true for some of the environmental and human security problems of the future (that are being created today). Thus, there is a true need to allow alternative perspectives to 'corrupt' one's own thinking. Those who emphasize military security at the expense of other security issues, most especially US analysts and policymakers, may fundamentally be walking into a self-fulfilling paradox: the

\footnotetext{
9 For examples of the 'capabilities' approach, see the draft report of the DAC Informal Network on Poverty Reduction, available at http:/ / www.etcint.org/PDF/DAC\%20vol\%201.pdf (accessed 25 October 2004), as well as UNEP (2004) and Sen (1987).
} 
more one seeks to avoid military intervention, the more one is driven to militarily intervene because of failure to recognize contrary security issues and to deal with them in a pre-emptive or preventive manner. The old cliché that describes this trap is also an apt reminder: If all you have is a hammer, then every problem begins to look like a nail. Surely, as the interventions in Somalia, the Balkans, Afghanistan, and Iraq illustrate, traditional applications of military security may not be the best, and are certainly not the only, viable strategic instruments.

Although it remains to be seen how deep or permanent the damage caused by the 2003 US-European transatlantic rift (over intervention in Iraq) will be, there are already warning signals. As Kagan $(2004,75)$ notes, a crisis of legitimacy has emerged in the post-911 era:

The fact remains that the Kosovo war was illegal, and not only because it lacked Security Council authorization: Serbia had not committed any aggression against another state but was slaughtering its own ethnic Albanian population. The intervention therefore violated the sovereign equality of all nations, a cardinal principle of the UN Charter and the bedrock principle of international law for centuries. During the Kosovo conflict, Henry Kissinger warned that 'the abrupt abandonment of the concept of national sovereignty' risked unmooring the world from any notion of order, legal or otherwise. Many Europeans rejected this complaint at the time. Back then . . . before the Iraq war . . . they did not seem to believe that international legitimacy resided exclusively with the Security Council, or in the UN Charter, or even in traditional principles of international law. Instead they believed in the legitimacy of their common postmodern moral values.

In 2003, during the dispute over Iraq, those postmodern values did not seem to be universally shared or even understood. Moreover, if, in the future, the United States will always forgo 'international' interests for the sake of 'national' interests, the rift will grow even wider.

Part of this rift lies in how states and regions differ in their commitment to human and national security. It is conceivably possible (given that the United Nations will likely remain hobbled and incapable of effective longterm security implementation actions) that the European Union, under the emerging Common Security and Defence Policy, may become the 'lead' agency for long-term multi-level, multi-referent, and interdependent security initiatives - to include 'out of area' operations. It is less likely that the United States will lead in this arena.

All of these troubling outcomes are only exacerbated in the agony of those who are pushed aside, annihilated, or remain fortunate enough to flee (with nothing). In redrawing the map of the future, the focus, again, must shift to asking: What are the long-term consequences of failing to recognize creeping vulnerabilities? While it may at first seem a stretch, for example, it seems pertinent to recall that the 'preservation' of displaced Arabs in refugee camps following the 1967 Arab-Israeli War led, decades later, to the intifadas of the 1980s, the 1990s, and the 21st century (Goldstone, 2002: 21). The dis- 
placement of Hutus and Tutsis from the Rwanda genocide of 1994 had a direct impact on the disaster in the Democratic Republic of Congo, where estimates place the death toll from conflict in excess of 3.5 million since 'liberation' in 1997. Indeed, the roots of a potential Balkan conflict 20 years from now can be found in the weak economic conditions, corrupt political institutions, and bands of angry young men with nowhere to go and nothing to look forward to in the streets and ruined foundations of Kosovo, Bosnia, and Serbia.

Thus, in considering whether such frameworks might be viable for the future, it is important to step away from applying such a template to only crisis response or conditions of extreme vulnerability. Arguably, the roots of the disasters in Bosnia and Herzegovina and Kosovo did not begin in 1998; rather, they began in the aftermath of World War II, and flared up, again and again, during the 1980s - as illustrations of creeping vulnerability. Yet, the consequence and the cost to the 'West' of not investing in the Balkans in the right way and early enough could be at least 50 years of political and military engagement - and economic assistance. In comparison, the reconstruction of Iraq is an even more daunting task.

\section{In Lieu of Closure}

Although it seems attractive to focus on exclusionary concepts that insist on desecuritization, privileged referent objects, and the 'belief' that threats and vulnerabilities are little more than social constructions (Grayson, 2003), all these concepts work in theory but fail in practice. While it may be true that national security paradigms can, and likely will, continue to dominate issues that involve human security vulnerabilities - and even in some instances mistakenly confuse 'vulnerabilities' as 'threats' - there are distinct linkages between these security concepts and applications. With regard to environmental security, for example, Myers (1986: 251) recognized these linkages nearly two decades ago:

National security is not just about fighting forces and weaponry. It relates to watersheds, croplands, forests, genetic resources, climate and other factors that rarely figure in the minds of military experts and political leaders, but increasingly deserve, in their collectivity, to rank alongside military approaches as crucial in a nation's security.

Ultimately, we are far from what O'Hanlon \& Singer (2004) term a global intervention capability on behalf of 'humanitarian transformation'. Granted, we now have the threat of mass casualty terrorism anytime, anywhere - and states and regions are responding differently to this challenge. Yet, the global community today also faces many of the same problems of the 1990s: civil wars, faltering states, humanitarian crises. We are nowhere closer to 
addressing how best to solve these challenges, even as they affect issues of environmental, human, national (and even 'embedded') security.

Recently, there have been a number of voices that have spoken out on what the International Commission on Intervention and State Sovereignty has termed the 'responsibility to protect': ${ }^{10}$ the responsibility of some agency or state (whether it be a superpower such as the United States or an institution such as the United Nations) to enforce the principle of security that sovereign states owe to their citizens. Yet, the creation of a sense of urgency to act-even on some issues that may not have some impact for years or even decades to come - is perhaps the only appropriate first response. The real cost of not investing in the right way and early enough in the places where trends and effects are accelerating in the wrong direction is likely to be decades and decades of economic and political frustration - and, potentially, military engagement. Rather than justifying intervention (especially military), we ought to be justifying investment.

Simply addressing the immensities of these challenges is not enough. Radical improvements in public infrastructure and support for better governance, particularly in states and municipalities (especially along the Lagos-Cairo-Karachi-Jakarta arc), will both improve security and create the conditions for shrinking the gap between expectations and opportunity.

A real debate ought to be taking place today. Rather than dismissing 'alternative' security foci outright, a larger examination of what forms of security are relevant and right among communities, states, and regions, and which even might apply to a global rule-set - as well as what types of security are not relevant - seems appropriate and necessary. If this occurs, a truly remarkable tectonic shift might take place in the conduct of international relations and human affairs.

Perhaps, in the failure of states and the international community to respond to such approaches, what is needed is the equivalent of the 1972 Stockholm conference that launched the global environmental movement and established the United Nations Environmental Programme (UNEP), designed to be the environmental conscience of the United Nations. Similarly, the UN Habitat II Conference in Istanbul in 1996 focused on the themes of finding adequate shelter for all and sustaining human development in an increasingly urbanized world. Whether or not these programs have the ability to influence the future's direction (or receive wide international support) is a matter of some debate. Yet, given that the most powerful states in the world are not currently focusing on these issues to a degree sufficient to produce viable implementation plans or development strategies, there may well need to be a 'groundswell' of bottom-up pressure, perhaps in the form of a global citizenry petition to push the elusive world community toward collective action.

${ }^{10}$ See, for example, United Nations Commission on Human Security (2003). 
Recent history suggests that military intervention as the first line of response to human security conditions underscores a seriously flawed approach. Moreover, those who advocate that a state's disconnectedness from globalization is inversely proportional to the likelihood of military (read: US) intervention fail to recognize unfolding realities (Barnett, 2003, 2004). Both middle-power and major-power states, as well as the international community, must increasingly focus on long-term creeping vulnerabilities in order to avoid crisis responses to conditions of extreme vulnerability. Admittedly, some human security proponents have recently soured on the viability of the concept in the face of recent 'either with us or against us' power politics (Suhrke, 2004). At the same time, and in a bit more positive light, some have clearly recognized the sheer impossibility of international power politics continuing to feign indifference in the face of moral categories. As Burgess (2004: 278) notes, 'for all its evils, one of the promises of globalization is the unmasking of the intertwined nature of ethics and politics in the complex landscape of social, economic, political and environmental security'.

While it is still not feasible to establish a threshold definition for human security that neatly fits all concerns and arguments (as suggested by Owen, 2004: 383), it would be a tragic mistake to assume that national, human, and environmental security are mutually harmonious constructs rather than more often locked in conflictual and contested opposition with each other. Moreover, aspects of security resident in each concept are indeed themselves embedded with extraordinary contradictions. Human security, in particular, is not now, nor should likely ever be, the mirror image of national security.

Yet, these contradictions are not the crucial recognition here. On the contrary, rather than focusing on the security issues themselves, we should be focusing on the best multi-dimensional approaches to confronting and solving them. One approach, which might avoid the massive tidal impact of creeping vulnerabilities, is to sharply make a rudder shift from constant crisis intervention toward strategic planning, strategic investment, and strategic attention. Clearly, the time is now to reorder our entire approach to how we address - or fail to address - security.

* P. H. Liotta is Professor of Humanities at Salve Regina University, Newport, RI, and Executive Director of the Pell Center for International Relations and Public Policy. Recent work includes The Uncertain Certainty: Human Security, Environmental Change, and the Future Euro-Mediterranean (Lexington, 2003), Mapping Macedonia: Idea and Identity (coauthored with C. R. Jebb; Praeger, 2004), and the co-edited Security and Environment in the Mediterranean: Conceptualising Security and Environmental Conflict (Springer, 2003). He is grateful for the generous and helpful comments provided by three anonymous reviewers for this article. E-mail: phliotta@cox.net. 


\section{References}

Ash, Timothy Garton, 1998. 'Europe's Endangered Liberal Order', Foreign Affairs 77(2): 51-66.

Barbour, Ian, 1993. Ethics in an Age of Technology: The Gifford Lectures, Volume 2, 19901991. San Francisco, CA: Harper.

Barnett, Thomas P. M., 2003. 'The Pentagon's New Map: Why We're Going to War and Why We'll Keep Going to War', Esquire 139(March): 174-181.

Barnett, Thomas P. M., 2004. The Pentagon's New Map: War and Peace in the Twenty-First Century. New York: G. P. Putnam.

Blair, Tony, 1999. 'The Doctrine of the International Community', delivered to the Chicago Press Club during the US-led NATO intervention in Kosovo in 1999; available at http:/ / www.number-10.gov.uk/output/Page1297.asp (accessed 1 March 2004).

Brauch, Hans Günter, 2000. 'Partnership Building Measures of Long-Term Non-Military Challenges Affecting North-South Relations', in Abdelwahab Biad, Hans Günter Brauch \& Antonio Marquina, eds, Euro-Mediterranean Partnership for the 21st Century. London: Macmillan (281-318).

Burgess, J. Peter, 2004. 'Commentary', Security Dialogue 35(3): 275-278.

Bush, George W., 2002. 'Introduction' and 'II. Champion Aspirations for Human Dignity', in the National Security Strategy of the United States of America; available at http:// www.whitehouse.gov/nsc/nss.html (accessed 1 March 2004).

Buvinić, Mayra \& Andrew R. Morrison, 2000. 'Living in a More Violent World', Foreign Policy (118): 58-72.

Buzan, Barry, 2004. 'A Reductionist, Idealistic Notion That Adds Little Analytical Value', Security Dialogue 35(3): 369-370.

Buzan, Barry \& Ole Wæver, 2003. Regions and Powers: The Structure of International Security. Cambridge: Cambridge University Press.

Buzan, Barry; Ole Wæver \& Jaap de Wilde, 1998. Security: A New Framework for Analysis. Boulder, CO: Lynne Rienner.

Courtney, Hugh; Jane Kirkland \& Patrick Viguerie, 1997. 'Strategy Under Uncertainty', Harvard Business Review, 1 November: 66-79.

Gleditsch, Nils-Petter, 2003. 'Environmental Conflict: Neomalthusians vs. Cornucopians', in Hans Günter Brauch, P. H. Liotta, Antonio Marquina, Paul Rogers \& Mohammed El-Sayed Selim, eds, Security and Environment in the Mediterranean: Conceptualizing Security and Environmental Conflict. Berlin: Springer (477-485).

Goldstone, Jack, 2002. 'Population and Security: How Demographic Change Can Lead to Violent Conflict', Journal of International Affairs 56(1): 3-21.

Grayson, Kyle, 2003. 'Securitization and the Boomerang Debate: A Rejoinder to Liotta and Smith-Windsor', Security Dialogue 34(3): 337-343.

Grayson, Kyle, 2004. 'A Challenge to Power over Knowledge in Traditional Security Studies', Security Dialogue 35(3): 357.

Hoogensen, Gunhild \& Svein Vigeland Rottem, 2004. 'Gender Identity and the Subject of Security', Security Dialogue 35(2): 155-171.

Huntington, Samuel P, 2004. Who Are We? The Challenges to America's National Identity. New York: Simon \& Schuster.

Kagan, Robert, 2004. 'America's Crisis of Legitimacy', Foreign Affairs 83(2): 65-87.

Kay, Sean, 2004. 'Globalization, Power, and Security', Security Dialogue 35(1): 9-25.

Khong, Yuen Foong, 2001. 'Human Security: A Shotgun Approach to Alleviating Human Misery?', Global Governance 7(3): 231-237. 
Liotta, P. H., 2002a. 'Boomerang Effect: The Convergence of National and Human Security', Security Dialogue 33(4): 473-488.

Liotta, P. H., 2002b. 'Chaos as Strategy', Parameters (Summer): 47-56; available at http://carlisle-www.army.mil/usawc/Parameters/02summer/liotta.htm (accessed 22 October 2004).

Liotta, P. H., 2002c. 'Converging Interests and Agendas: The Boomerang Returns', Security Dialogue 33(4): 495-498.

Liotta, P. H., 2004. 'A Concept in Search of Relevance', Security Dialogue 35(3): 362-363.

Manning, Richard, 2004. 'The Oil We Eat: Following the Food Chain Back to Iraq', Harper's, February: 37-45.

Matsumae, Tatsuro \& L. C. Chen, eds, 1995. Common Security in Asia: New Concept of Human Security. Tokyo: Tokai University Press.

Møller, Bjørn, 2003. 'National, Societal and Human Security: Discussion - Case Study of the Israel-Palestine Conflict', in Hans Günter Brauch, P. H. Liotta, Antonio Marquina, Paul Rogers \& Mohammed El-Sayed Selim, eds, Security and Environment in the Mediterranean: Conceptualizing Security and Environmental Conflict. Berlin: Springer (277-288).

Montaigne, Fen, 2002. 'Water Pressure', National Geographic, September: 2-33.

Myers, Norman, 1986. 'The Environmental Dimension to Security Issues', The Environmentalist 6(4): 251-257.

National Intelligence Council, 2001. Global Trends 2015: A Dialogue about the Future with Nongovernment Experts. Washington, DC; available at http://www.odci.gov/cia/ reports/globaltrends2015/index.html (accessed 24 January 2005).

Nef, Jorge, 1999. Human Security and Mutual Vulnerability: The Global Economy of Development and Underdevelopment, 2nd edn. Ottawa: International Development Research Centre.

Niebuhr, Reinhold, 1932. Moral Man and Immoral Society: A Study in Ethics and Politics. New York: Charles Scribner's Sons.

Niebuhr, H. Richard, 1978. The Responsible Self: An Essay in Christian Moral Philosophy. Introduction by James M. Gustafson. San Francisco, CA: Harper \& Row.

Norton, Richard, 2003. 'Feral Cities', Naval War College Review, Autumn: 97-106.

O'Hanlon, Michael \& P. W. Singer, 2004. 'The Humanitarian Transformation: Expanding Global Intervention Capacity', Survival 46(1): 77-99.

Owen, Taylor, 2004. 'Human Security - Conflict, Critique, and Consensus: Colloquium Remarks and a Proposal for a Threshold-Based Definition', Security Dialogue 35(3): 373-387.

Packer, George, 2004. 'War and Ideas', The New Yorker, 5 July: 29/32.

Paris, Roland, 2001. 'Human Security: Paradigm Shift or Hot Air?', International Security 26(2): 87-102.

Perlman, Janice, 2002, 'The Metamorphosis of Marginality: From Myth to Reality in the Favelas in Rio de Janeiro, 1969-2002', unpublished draft, quoted in Ellen BrennanGalvin, 'Crime and Violence in an Urbanizing World', Journal of International Affairs 56(1): 123.

Rawls, John, 1971. A Theory of Justice. Cambridge, MA: Belknap.

Rothschild, Emma, 1995. 'What Is Security? The Quest for World Order', Dædulus: The Journal of the American Academy of Arts and Sciences 124(3): 53-98.

Scott, James C., 1977. The Moral Economy of the Peasant. New Haven, CT: Yale University Press.

Security Dialogue, 2004. 'What Is "Human Security"', symposium edited by J. Peter Burgess \& Taylor Owen, Security Dialogue 35(3): 345-371. 
Sen, Amartya, 1987. The Standard of Living. Cambridge: Cambridge University Press.

Smith-Windsor, Brooke A., 2002. 'Terrorism, Individual Security, and the Role of the Military: A Reply to Liotta', Security Dialogue 33(4): 489-494.

Stiglitz, Joseph, 2002. Globalization and Its Discontents. New York: W. W. Norton.

Stoett, Peter, 1999. Human and Global Security: An Explanation of Terms. Toronto: University of Toronto Press.

Suhrke, Astri, 1999. 'Human Security and the Interests of the State', Security Dialogue 30(3): 265-276.

Suhrke, Astri, 2004. 'A Stalled Initiative', Security Dialogue 35(3): 365.

Tehranian, Majid, ed., 1999. Worlds Apart: Human Security and Global Governance. London: I. B. Tauris.

Thomas, Caroline \& Peter Wilkin, eds, 1999. Globalization, Human Security, and the African Experience. Boulder, CO: Lynne Rienner.

United Nations Centre for Human Settlements, 1996. Global Report on Human Settlements. Oxford: Oxford University Press.

United Nations Commission on Human Security, 2003. Protecting and Empowering People; available at: http://www.humansecurity-chs.org/finalreport/outline.html (accessed 19 June 2003).

United Nations Development Programme (UNDP), 1994. Human Development Report: Annual Report. New York: UNDP.

United Nations Environment Programme (UNEP), 2004. Exploring the Links: Human WellBeing, Poverty, \& Ecosystem Services. Winnipeg: International Institute for Sustainable Development.

United States Government Interagency Working Group, 2000. 'International Crime Threat Assessment, December'; available at: http://www.fas.org/irp/threat/ pub45270index.html (accessed 13 August 2003).

Wæver, Ole, 1995. 'Securitization and Desecuritization', in Ronnie D. Lipschutz, ed., On Security. New York: Columbia University Press (46-86).

Zvekić, Ugljesa \& Anna Alvazzi del Frate, eds, 1995. Criminal Victimization in the Developing World. Rome: United Nations Interregional Crime and Justice Research Institute/UNICRI. 